\title{
Estudo de Caso da Atuação da Defensoria Pública em Hipóteses de Feminicídio na Comarca de João Pessoa - PB
}

\section{Case Study of the Performance of the Public Defender's Office in Hypotheses of "Femicide" in the Judicial District of João Pessoa -PB}

\author{
Gustavo Barbosa de Mesquita Batista ${ }^{1}$, Nathálya Lins Silva ${ }^{1}$.
}

\begin{abstract}
RESUMO
A Defensoria Pública como instituição do Estado enfrenta o dilema de, por um lado, proteger as mulheres vítimas de violência, promovendo os Direitos Humanos, por outro lado, defender os agressores em vulnerabilidade econômica. Como atuar nessas duas frentes sem perceber uma contradição? Seria possível explicitar limites éticos para essa dupla atuação da Defensoria e encontrar formas de reduzir essa contradição sem criar obstáculos para uma defesa plena e técnica dos agressores socialmente vulneráveis? Para tanto, este estudo de caso buscou nos discursos comuns apresentados pelos próprios Defensores Públicos e na análise dos conteúdos derivados a partir da hipótese estabelecida em comparação com tais discursos, elementos que propiciem novas estratégias de lidar com o paradoxo apresentado sem perder as condições de atuação da Defensoria Pública no atendimento dos seus fins institucionais. É necessário aprimorar os discursos e as políticas públicas a fim de produzir um sistema de proteção mais abrangente que nos permita superar essa tragédia estatística de mortes violentas de mulheres por questão de gênero.
\end{abstract}

Palavras-chave: Defensoria Pública; Violência de Gênero; Feminicídio.

\begin{abstract}
The Public Defender's Office as a State institution faces the dilemma of protecting women victims of violence on the one hand, promoting human rights, while, on the other hand, defending women aggressors in economic vulnerability. How to act on these two fronts without realizing a contradiction? Would it be possible to clarify ethical limits for this dual role of the defense and to find ways to reduce this contradiction without creating obstacles for a fair and technical defense of socially vulnerable aggressors? To this end, it sought in the common speeches presented by the Public Defenders themselves and in the analysis of the contents derived from the hypothesis established in comparison with such speeches, elements that provide new strategies to deal with the paradox presented without losing the conditions of performance of the Public Defender in the fulfillment of its institutional purposes. It is necessary to improve public speeches and policies in order to produce a more comprehensive protection system that will allow us to overcome this statistical tragedy of violent deaths of women due to gender.
\end{abstract}

Keywords: Public Defender's Officer; Gender Violence; "Femicide".

${ }^{1}$ Universidade Federal da Paraíba (UFPB)

*E-mail: nathalyalinss02@gmail.com 


\section{INTRODUÇÃO}

A Defensoria Pública é uma instituição estatal com previsão na Constituição brasileira (art. $5^{\circ}$, LXXIV), em que estabelece, como direito fundamental, a assistência jurídica integral e gratuita oferecida pelo Estado, tendo suas prerrogativas e funções no art. 134 da Carta Magna, tomando por base a metagarantia do "direito a ter direitos" (COSTA, 2015, p.202). Assim, esta instituição, quanto à sua qualificação, é um instrumento de expressão do regime democrático, possuindo o dever de promover os direitos humanos e defender as pessoas socialmente vulneráveis.

A partir de sua primeira função institucional, consoante a Defensora Pública do Rio de Janeiro, Renata Costa (2015, p. 203), extrai-se uma posição positiva, isto é, de assegurar o acesso de gozo dos Direitos Humanos, como também uma posição negativa, ou seja, de abster-se de determinadas atitudes que ratifiquem a violação destes direitos. Em outras palavras, não poderia o(a) Defensor(a) promover os direitos humanos e, ao mesmo tempo, sustentar as violações de direitos. Paradoxo esse que pode ocorrer em determinadas situações, como quando do exercício de sua função de defesa, tenha que atuar em favor de determinados agressores vulneráveis.

Partindo das prerrogativas listadas, fez-se necessário a formação e a prática da pesquisa, base deste artigo, com a finalidade de analisar os processos judiciais de feminicídio julgados no Tribunal do Júri da Comarca de João Pessoa/PB, em que tem como frente da defesa técnica a Defensoria Pública do Estado da Paraíba, explorando, assim, a atuação da Defensoria Pública na elaboração da tese de defesa do réu, a fim de identificar os fatores sociais e jurídicos que influenciam na sua elaboração, uma vez que se aplica o princípio da plenitude de defesa; E, igualmente, as dificuldades e contradições estabelecidas nesta argumentação defensiva, em virtude do papel também importante da Defensoria Pública na defesa das vítimas de violência doméstica.

Os casos de feminicídio persistem no cotidiano nacional e alertam para a necessidade de investigações que permitam modificar os paradigmas culturais e estruturais. Os indicadores mais recentes dos dados de violência no Brasil dão conta de que apesar dos avanços normativos e do aparato institucional, a curva ainda é ascendente com relação a este fenômeno criminológico. Observamos isso tanto no Atlas da Violência publicado pelo IPEA em 2018 (IPEA, 2018, p. 44-55) como no Mapa de Violência de 2015 organizado pela Faculdade Latino Americana de Ciências Sociais (FLACSO) com 
o tema: Homicídio de Mulheres no Brasil. Ambos os documentos retratam que o cotidiano nacional é permeado pela violência contra mulher, não se tratando de um “evento ocasional" e sem maiores repercussões, dado a gravidade de suas consequências.

Desta forma, Pesquisas e artigos com este objeto se justificam e se somam no esclarecimento de um fenômeno extremamente nocivo de violência e pela ruptura de paradigmas que pode abrir margem para políticas de prevenção e proteção às mulheres vítimas de violência mais eficientes. Trata-se de uma matéria interdisciplinar que exige a confluência de saberes que vão desde a política criminal, o Direito Penal e a criminologia, até os estudos de gênero, a linguística e a semiótica (RASTIER, 2010) como instrumentos de reconhecimento e de ressignificação da ação comunicativa a ser alcançada para minimização da tragédia ensejada pelos altos índices de feminicídio observados no Brasil.

\section{ABORDAGEM METODOLÓGICA}

O Estudo para o presente artigo foi desenvolvido por intermédio do método de abordagem hipotético-dedutivo. Dessa forma, houve a verificação do problema pela análise dos discursos institucionais em conflito, no âmbito da Defensoria Pública -; a demonstração de hipótese para busca de uma solução - por meio da conciliação entra as funções, igualmente relevantes, da Defensoria Pública (defender juridicamente os hipossuficientes e promover os direitos humanos) e a certificação da eficácia da hipótese.

Os métodos de procedimento foram: o empírico e o estatístico. Em relação ao método empírico, destaca-se o acompanhamento das audiências ocorridas no Plenário do Tribunal do Júri da Comarca de João Pessoa - PB, com a finalidade de analisar a linguagem empregada nos debates orais e o julgamento feito pelos jurados leigos, dentre outros aspectos pessoais das partes envolvidas.

A análise foi feita mediante o preenchimento de um questionário previamente elaborado em comum por parte dos autores do artigo, com questões que envolviam os seguintes indicadores: idade do réu e da vítima; classe social do réu e da vítima; medida de proteção da Lei Maria da Penha imposta antes do fato; motivação do réu; enquadramento da qualificação de Feminicídio nos fatos narrados; tese de acusação e tese de defesa.

Ainda relacionado ao método empírico, destaca-se que foi aplicado um questionário paras as Defensoras Públicas do Estado da Paraíba, a fim de saber seu posicionamento acerca da atuação da Defensoria no Tribunal do Júri em crimes de feminicídio e acerca das políticas públicas de direitos humanos realizadas pela Defensoria na proteção à 
mulher vítima de violência doméstica. É importante pontuar que, juntamente ao questionário, as Defensoras assinaram um Termo de Consentimento Livre e Esclarecido como forma de autorização para a publicação dos dados colhidos e de seus respectivos nomes.

As perguntas formuladas às Defensoras Públicas foram:

1. Na construção da Defesa técnica em Plenário, pode-se destacar, por haver uma equipe de júri na Defensoria, a chegada do processo "pronto" para o Defensor(a) analisá-lo e elaborar sua tese defensiva. Você acha que existe um certo "cerceamento de defesa", por muitas vezes não ser o mesmo o defensor que acompanhou o caso do início do processo, ou quando durante as investigações? Por exemplo, por muitas vezes, presenciei situações em que o Defensor apenas falou alguns minutos com o assistido antes do júri.

2. Da pergunta anterior, surge a indagação sobre a possibilidade que o defensor tem de investigar. Por exemplo, quando a tese é negativa de autoria e há a possibilidade de encontrar outro suspeito pelo crime, o Defensor(a) não possui instrumentos ou estrutura (acho que é a palavra mais adequada) para fomentar a constituição deste tipo de prova, principalmente se o júri for feito pela equipe de júri, em que não houve o acompanhamento processual. Você concorda com esse pensamento?

3. O que você acha sobre existir uma equipe de júri pelo fato de alguns Defensores se esquivarem de fazerem júris em suas Comarcas?

4. Quanto Defensora Pública, mulher e feminista, existe conflito ético em elaborar uma defesa para aquele, consoante as provas do processo, cometeu o crime de feminicídio? Digo, neste momento, você pediria a absolvição por clemência, já que o júri não precisa fundamentar sua decisão?

5. E sobre o pedido de desclassificação para homicídio privilegiado? Qual a "possibilidade" de enquadrar o feminicídio como crime passional?

6. Sobre a questão dos assistidos terem receio quando verem que é uma mulher a Defensora Pública que irá fazer a defesa do mesmo júri, motiva-os a constituírem advogados particulares?

7. As Defensoras possuem alguma dificuldade institucional em exercer a sua profissão em decorrência de machismo ou da concepção de uma sociedade patriarcal, principalmente no interior dos Estados?

8. Na sua opinião, houve uma modificação na passagem de "crime de amor" para "crime de ódio"? Como a defesa lida com essas concepções/ expressões?

9. Na sua opinião, como a Defensoria poderia agir com políticas de prevenção e proteção às mulheres vítimas de violência?

10. Quais aspectos linguísticos (não) deveriam ser abordados na defesa do réu? Por exemplo o uso de "matou por amor", dentre expressões que podem sugerir a caracterização de uma sociedade patriarcal e machista.

11. Na sua opinião, quais são as principais dificuldades para a construção da plenitude de defesa (já que envolve aspectos morais, políticos, sociais, dentre outros, além dos técnicos) nos crimes de feminicídio? 
A primeira entrevistada foi a Defensora Pública do Estado da Paraíba, Raissa Pacífico Palitot Remígio ${ }^{2}$, a qual possui atuação na $2^{\mathrm{a}}$ Vara Mista da Comarca de Patos/PB, que tem, igualmente, competência para julgar os casos de violência doméstica. As perguntas foram direcionadas a sua atuação nos casos de violência doméstica, retratando a percepção da defesa de autor de violência de gênero e os problemas estruturais do sistema penal ao lidar com os crimes ocorridos em razão do gênero.

A segunda entrevistada foi a Defensora Pública do Estado da Paraíba Monaliza Maelly Fernandes Montinegro, a qual está atualmente lotada na $1^{\mathrm{a}}$ Vara Mista da Comarca de Patos/PB, atuando como defesa no Tribunal do Júri da Comarca. A defensora também já implantou grupos reflexivos nas Comarcas em que ficou em exercício: Pocinhos/PB e Patos/PB. É importante ressaltar que o grupo reflexivo na Comarca de Patos/PB está se ajustando para em breve atuar de forma efetiva. As perguntas foram direcionadas ao desenvolvimento do grupo reflexivo para homens autores de violência doméstica na Comarca de Pocinhos/PB e seus resultados.

Quanto ao método estatístico, foram analisados dados produzidos por revistas de direito, pelo anuário de segurança pública da Paraíba (2019) e por artigos científicos que tiveram como objeto de pesquisa os crimes ocorridos em razão de gênero. A pesquisa também foi desenvolvida por meio da técnica de documentação indireta, ou seja, é uma pesquisa teórica, bibliográfica e documental; os procedimentos instrumentais foram: livros, artigos científicos, revistas de direito, pesquisas acadêmicas, legislação e jurisprudências. A Pesquisa teve um perfil quantitativo e qualitativo com relação aos dados coletados. Por fim a pesquisa é descritiva por retratar a forma que o sistema penal lida com a violência doméstica e as partes envolvidas, além da atuação da Defensoria Pública do Estado.

\section{DISCUSSÃO}

Conforme as figuras abaixo, observa-se números de Crimes Violentos Letais Intencionais (CVLI) contra a Mulher, no Estado da Paraíba, e a comparação da taxa de homicídio de mulheres no Brasil:

\footnotetext{
2 A Defensora Pública do Estado da Paraíba, Dra. Raissa Pacífico Palitot Remígio, atualmente, é coordenadora da Coordenadoria de Defesa da Mulher da Defensoria Pública do Estado da Paraíba, fato novo desde a produção da pesquisa acadêmica e seus resultados.
} 
Figura 1 - Comparação entre o número de mulheres vítimas de Crimes Violentos

Letais Intencionais (CVLI) e Feminicídios.

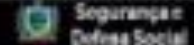

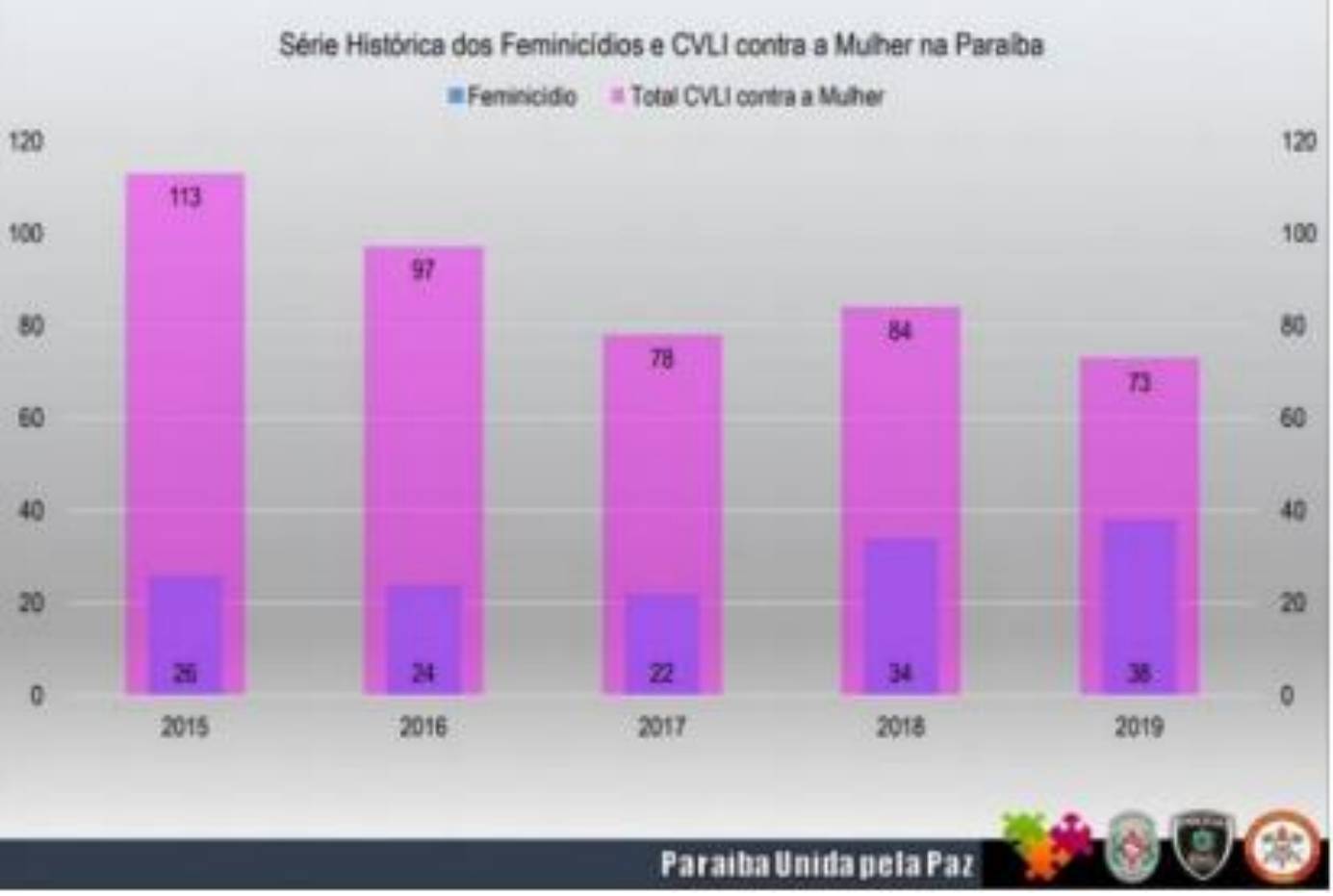

Fonte: Anuário de Segurança Pública na Paraíba (2019).

Figura 2 - Comparação da taxa de homicídio de mulheres por grupo de 100 mil Mulheres no Brasil e na Paraíba.

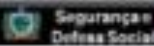

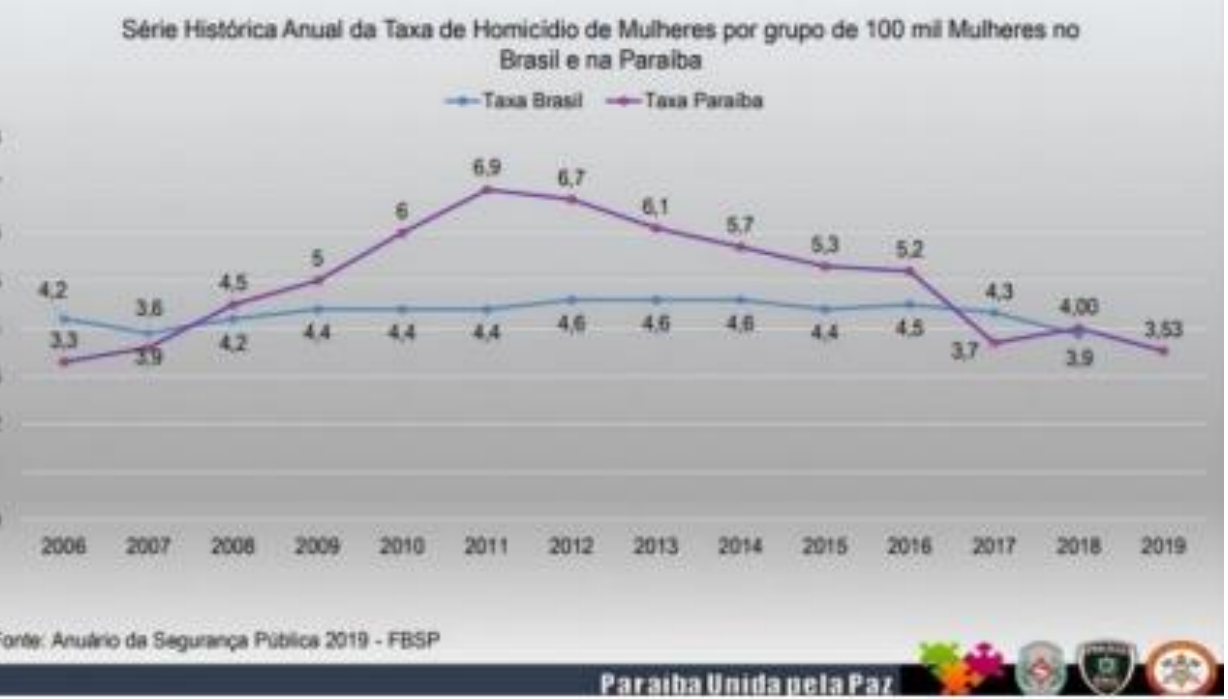

Fonte: Anuário de Segurança Pública na Paraíba (2019) 
Buscando registrar o cenário da Paraíba frente ao feminicídio, na primeira figura, tem-se que, embora a quantidade de homicídios de mulheres tenha diminuído, entre 2015 e 2019, no Estado da Paraíba, a porcentagem relativa ao feminicídio aumentou, sendo, inclusive, em 2019, a maior dentre os anos analisados. Ademais, no que tange à segunda figura, destaca-se a superioridade da taxa de homicídio de mulheres da Paraíba em relação à média nacional.

O cenário desenvolvido pela violência de gênero originou-se de um modelo patriarcal de família bastante difundido no Ocidente e replicado no Brasil, havendo, assim, uma hegemonia do patriarcado com uma estruturação simbólica e cultural de dominação masculina (BOURDIEU, 2012). Essas questões exprimem as práticas utilizadas para o disciplinamento e modelação dos corpos femininos dentro desta estrutura, tecendo uma história da violência pertencente ao domínio da sexualidade e dirigida ao feminino, representando um acúmulo de experiências e tecnologias da violência interligadas à legitimação da estrutura social construída pelo patriarcado (PERROT, 2006). Essa desvalorização se expressa numa variedade de danos sofridos pelas mulheres, incluindo a violência e a exploração sexual, a violência doméstica generalizada; as representações banalizantes, objetificadoras e humilhantes na mídia; o assédio e a desqualificação em todas as esferas da vida cotidiana; a sujeição às normas androcêntricas, que fazem com que as mulheres pareçam inferiores ou desviantes e que contribuem para mantê-las em desvantagem, mesmo na ausência de qualquer intenção de discriminar; a discriminação atitudinal; a exclusão ou marginalização das esferas públicas e centros de decisão e a negação de direitos legais plenos e proteções igualitárias (FRASER, 2003, p. 14-15).

Esta condição de vulnerabilidade da pessoa implica ao Estado a necessidade de formular políticas públicas que possam promover a igualdade de gênero e de políticas criminais voltadas àquelas que forem vítimas de violência (OLIVEIRA, 2007, 55-78).

Consoante CAMPOS (2017, 217 - 286), o Paradigma de Gênero também precisava direcionar as teses criminológicas defensivas, especificar a análise cultural e crítica como argumentos para a abordagem do fenômeno da violência doméstica e de gênero e estipular políticas públicas de proteção adequadas às vítimas, sendo essas premissas aplicáveis a Defensoria Pública. Do conflito entre a eficácia dos direitos fundamentais de proteção às vítimas de violência em oposição ao direito fundamental a contraditório e à ampla defesa (SARLET, 2003), surgem implicações, desde a dificuldade de atribuição da qualificadora 
de feminicídio à violência de gênero presente em nosso cotidiano até a análise de vulnerabilidades sociais e os critérios de imputação. Essas questões apontam para a necessidade de transpor a análise comum dos "crimes de amor" para a direção dos "crimes de ódio" ou dos "crimes estruturais", compreendendo diversas tonalidades ou aspectos próprios tomados neste percurso discursivo e de reconhecimento das vítimas de violência.

Contudo, a defesa em plenário dos assistidos acusados deve ser plena. A plenitude de defesa não está limitada a aspectos técnicos, podendo ser utilizados fundamentos morais, religiosos, políticos e sociais. Assim, a Defensora Pública Renata Costa, com o intuito de harmonizar as prerrogativas da Defensoria (possibilitar o acesso à justiça e promover os direitos humanos), indica utilizar em plenário a seguinte pergunta aos jurados "se essa violência é resultado de séculos de discriminação, é justo ou proporcional imputá-la somente ao sujeito que está sentado no banco dos réus?” (COSTA, 2015, p. 207), sendo o réu também uma vítima da sociedade patriarcal.

Então aquele menino que nasce num lar onde não pode chorar, não pode brincar de boneca ou de amarelinha; é separado das meninas desde os primeiros anos de escola; vira um adolescente destinado aos esportes, lutas e etc..., não pode demonstrar seus sentimentos; torna-se um adulto que toma a cerveja cuja propaganda é uma mulher "gostosa", assiste os programas de TV onde essas moças dançam quase nua; acha muito chato discurso de mulher, especialmente quando tem opinião, odeia a esposa do melhor amigo pois ela "manda nele", etc... Caso esta pessoa seja abandonada pela esposa, irá reagir de forma desproporcional. Ainda assim persiste a angústia de se ela deve pagar sozinha por uma violação estrutural direitos humanos. (RENATA, 2015, p.207).

Com isso, ao invés de utilizar teses defensivas que alimentam uma cultura de discriminação contra a mulher, o(a) Defensor(a) Público(a), em sua função de promover os direitos humanos e de assistir juridicamente o réu, deverá fazer uma defesa ética do usuário da Defensoria, colocando em relevo a questão cultural que sustenta a discriminação e problematizando o papel do agressor, criado por esta cultura.

\section{A Defensoria Pública enquanto instituição que promove os direitos humanos: discurso institucional em conflito e o direito penal dos vulneráveis}

A Defensoria Pública, como instituição de previsão constitucional, tem a função precípua de efetivar o direito fundamental à assistência jurídica integral e gratuita àqueles que comprovarem a insuficiência de recursos (art. $5^{\circ}$, LXXIV, Constituição Federal). 
As funções institucionais da Defensoria Pública estão discorridas no $\operatorname{artigo} 4^{\circ}$ da Lei Complementar 132. Dentre elas, cabe destaque para o inciso III, em que prevê "promover a difusão e a conscientização dos direitos humanos, da cidadania e do ordenamento jurídico". Com base neste inciso, a Defensoria Pública do Estado da Paraíba possui um núcleo de direitos humanos, intitulado "Núcleo Especial dos Direitos Humanos e da Cidadania" (NECID), criado por meio da Resolução n ${ }^{\circ}$ 043/2017/CS/DPPB, visando a tutela e garantia destes direitos. O NECID possui subdivisões em coordenadorias, o que possibilita ainda mais a efetivação deste trabalho, sendo uma delas a Coordenadoria de Defesa da Mulher.

Com suas funções constitucionalmente delimitadas, faz-se necessário questionar uma determinada prática de defesa no Tribunal do Júri, em que, nos casos de feminicídios, tendem a revitimizar a mulher, utilizando julgamentos morais ou construindo a defesa do réu no "direito de matar" através de teses jurídicas como a legítima defesa da honra. Inclusive, em recente decisão, o Supremo Tribunal Federal (STF, 2021), ao apreciar medida cautelar em Arguição de Descumprimento de Preceito Fundamental (ADPF 779), declarou que a tese de legítima defesa da honra é inconstitucional, por contrariar os princípios constitucionais da dignidade da pessoa humana (art. $1^{\circ}$, III, da Constituição Federal de 1988), da proteção à vida e a da igualdade de gênero (art. $5^{\circ}$, da Constituição Federal de 1988).

A Defensoria Pública do Estado da Paraíba, além dos Defensores vinculados à Comarca respectiva, possui uma "equipe de júri" que atua apenas na fase do Plenário, formada por Defensores Públicos que atuam, principalmente, em júris ocorridos nos interiores, devido à grande demanda ou à impossibilidade do Defensor daquela Vara realizar o júri. Como participante desta equipe, estava a coordenadora da Coordenadoria de Defesa da Mulher, a qual era escolhida, inclusive, para fazer defesas de júris de feminicídios.

A Defensora Raissa Palitot, sobre o tema, assinalou que vê como problemático e antagônico o fato da defensora coordenadora atuar nas duas frentes, tanto protegendo a vítima quanto fazendo os júris de feminicídios, podendo haver um conflito com a amplitude da defesa técnica em relação ao réu no tribunal do júri ou ao longo do processo, além da possibilidade de gerar uma insegurança para as mulheres que buscassem o apoio institucional. 
Ademais, o não acompanhamento processual desde o início (pelo mesmo Defensor) ou a falta de contato com o réu para a construção de sua defesa, também compromete o exercício da plenitude de defesa. Esse cerceamento se verifica nos casos em que os Defensores, participantes da equipe de júri, se limitam aos autos para a elaboração da defesa, sem ter a possibilidade de fazer requerimentos ao longo da investigação criminal, por exemplo. Em resposta ao questionário aplicado, a Defensora Monaliza Maelly menciona que atualmente a Defensoria Pública não tem estrutura ainda para trabalhar com a investigação defensiva. A seguir será apresentado um quadro para melhor análise do questionário aplicado às Defensoras.

Quadro 1 - Questionário aplicado às Defensoras Públicas do Estado

\begin{tabular}{|l|l|}
\hline \multicolumn{1}{|c|}{ Perguntas } & \multicolumn{1}{|c|}{ Respostas } \\
\hline $\begin{array}{l}\text { Quanto Defensora Pública, mulher e feminista, } \\
\text { existe conflito ético em elaborar uma defesa } \\
\text { para aquele, consoante as provas do processo, } \\
\text { cometeu o crime de feminicídio? Isto é, vocêe } \\
\text { pediria a absolvição por clemência, já que o júri } \\
\text { não precisa fundamentar sua decisão? }\end{array}$ & $\begin{array}{l}\text { Defensora Raissa Palitot: Tem uma dificuldade } \\
\text { emocional por eu ser mulher e feminista, só que } \\
\text { nos processos penais, desde quando eu fui } \\
\text { estagiária, sempre tive uma postura muito } \\
\text { processos penais, além de ter uma visão } \\
\text { técnica, eu tenho uma visão muito ética. Eu } \\
\text { vejo que, eu nunca atuei no júri para pedir } \\
\text { absolvição a todo custo, vejo como antiético e } \\
\text { também porque tenho que respeitar a } \\
\text { Defensoria Pública quanto instituição, mesmo } \\
\text { havendo a soberania do veredito, possibilitando } \\
\text { a absolvição, ser essa a única tese, acho isso } \\
\text { antiético. A DPE também é um instrumento de } \\
\text { educação social em direitos humanos, eu acho } \\
\text { que num júri de feminicídio, se realmente tiver } \\
\text { prova de autoria e materialidade e não houve } \\
\text { nulidades, cabe ao defensor (a) público (a) } \\
\text { fazer do Plenário do júri um lugar de efetiva } \\
\text { veiculação em direitos humanos, mostrar que } \\
\text { não é apenas o processo penal, as investigações } \\
\text { policiais que vão acabar com o feminicídio, } \\
\text { explicar as origens do feminicídio que são a } \\
\text { cultura patriarcal, o machismo (explicar o que } \\
\text { é, conceituar) para os jurados e todos os } \\
\text { presentes. É exercer a defesa técnica e deixar as } \\
\text { emoções de lados. A defesa técnica também é } \\
\text { de direitos humanos, a ampla defesa. Deve-se } \\
\text { analisar se foram respeitadas as regras de jogo. } \\
\text { Não pediria clemência, embora explicasse aos } \\
\text { jurados que eles tinham esse direito. Mas não } \\
\text { usaria como tese, pois acha que haveria um } \\
\text { conflito ético. Isso se tivesse comprovada a } \\
\text { autoria e a materialidade. Não pediria } \\
\text { desclassificação para homicídio privilegiado, }\end{array}$ \\
\hline
\end{tabular}


ou passional. Realçou que é um conceito antigo, de uma sociedade patriarcalista.

As Defensoras possuíam alguma dificuldade Defensora Monaliza: Sim. O sistema de justiça institucional em exercer a sua profissão em por si só é um ambiente extremamente decorrência de machismo ou da concepção de machista. A justiça criminal mais ainda. uma sociedade patriarcal, principalmente no Elogios na Tribuna à nossa aparência, por interior? exemplo, é algo que tira nossa credibilidade e só ocorre com nós mulheres. Já aconteceu um caso de um réu que chegou pra mim dizendo que outro preso queria pagar um advogado para fazer o júri dele. Eu o convenci de que não precisava. No dia do plenário eu aconselhei a autodefesa dele e ele me tratou com desprezo. Fez tudo o contrário. No final, eu quase consegui uma absolvição $(4 \times 3)$. Consegui o privilégio e uma retirada de uma qualificadora. Se ele tivesse me ouvido, provavelmente teríamos conseguido.

Na sua opinião, houve uma modificação na Defensora Monaliza: A conscientização da passagem de 'crime de amor' para 'crime de sociedade a respeito do machismo passa pela ódio'? Como a defesa lida com essas superação da linguagem patriarcal e pelo concepções/ expressões? rompimento de mitos, como esse da ideia de que se mata por amor... Na minha opinião, as duas expressões são inadequadas. O machismo é um sistema estrutural e, como estrutura é, ele quem mata. Nessa concepção, não dá para dizer que o crime é de amor, tampouco de ódio. É um crime estrutural.

Defensora Raissa Palitot: Houve sim a passagem de "crime de amor" para o "crime de ódio", principalmente com a qualificadora. A defesa tem que explicar aos jurados. A criminalização veio como um combate a concepções machistas da sociedade, investigando, processando e condenando a pessoa que cometeu o feminicídio.

Na sua opinião, como a Defensoria poderia agir Defensora Monaliza: Sim. Precisamos disso com políticas de prevenção e proteção às pra ontem. Eu desenhei um projeto direcionado mulheres vítimas de violência? Quais aspectos às mulheres vítimas de violência. Esse projeto, linguísticos (não) deveriam ser abordados na infelizmente, ainda não foi executado porque defesa do réu? Por exemplo o uso de matou por nossa demanda no interior é muito alta e nós amor', dentre expressões que podem sugerir a não temos estrutura, nem tempo de correr atrás caracterização de uma sociedade patriarcal e de parcerias. O projeto tem três frentes: Uma, machista.

na formação dos profissionais da rede de atendimento da mulher, sobretudo do sistema de justiça. Outra, atendendo às mulheres vítimas de violência, capacitando-as, empoderando-as, formando lideranças e trabalhando com a justiça restaurativa. Outra, com a criação de grupos reflexivos para 


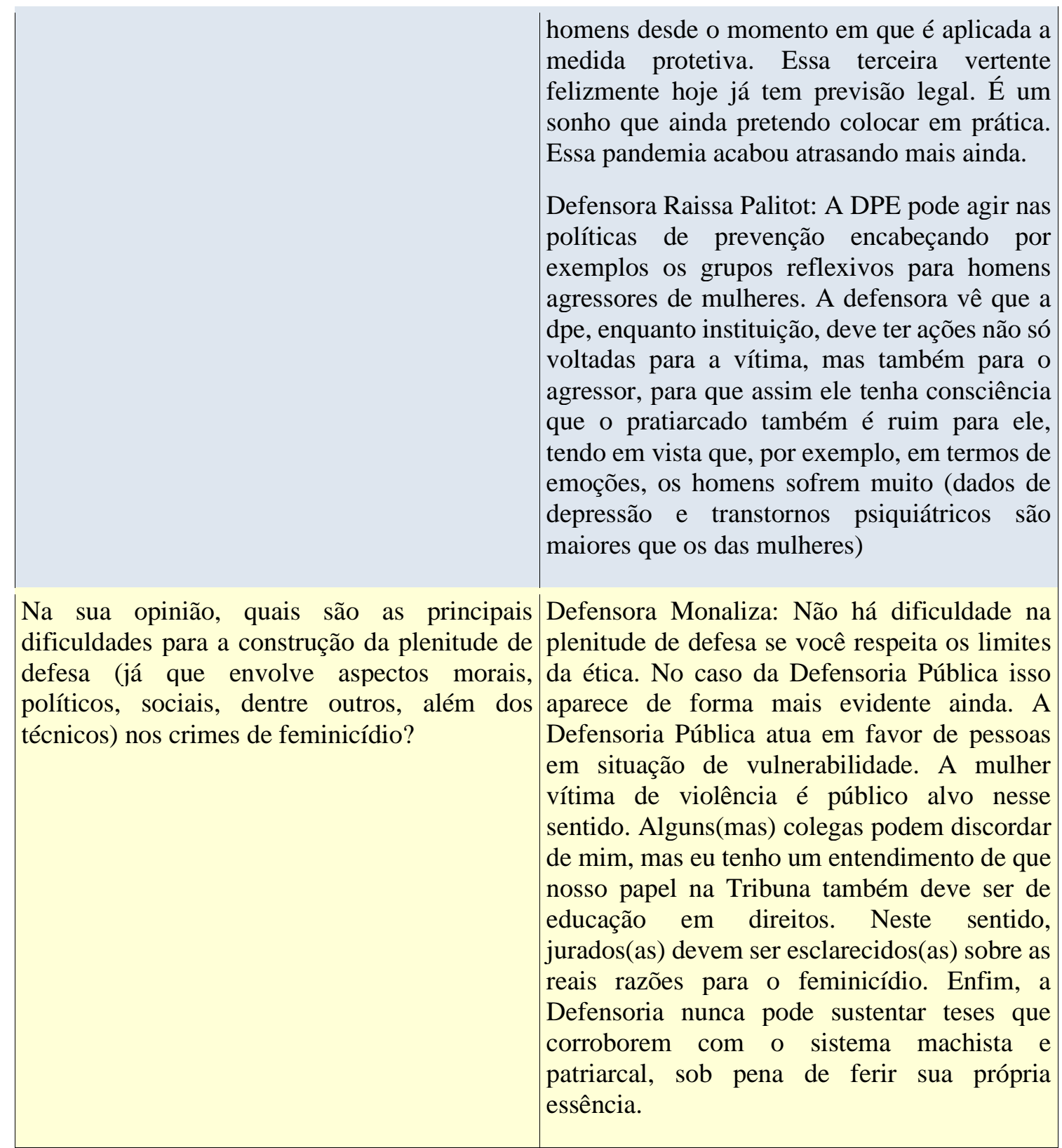

Fonte: Questionário elaborado pela pesquisadora bolsista Nathálya Lins da Silva, com orientação do Prof. Dr. Gustavo Batista, baseado em BOURDIEU (2012), BUTLER (2019),

FRASER (2006), COSTA (2015).

A Defensora Raissa Palitot, sobre o tema, assinalou que vê como problemático e antagônico o fato da defensora coordenadora atuar nas duas frentes, tanto protegendo a vítima quanto fazendo os júris de feminicídios, podendo haver um conflito com a amplitude da defesa técnica em relação ao réu no tribunal do júri ou ao longo do processo, além da possibilidade de gerar uma insegurança para as mulheres que buscassem o apoio institucional.

O projeto citado pela Defensora Monaliza está nos preparativos para execução em Patos/PB. Chama-se "A-colher" e possui três eixos de atuação. O primeiro eixo é 
direcionado aos homens autores de violência de gênero, os quais serão submetidos a um curso denominado "Homens de Verdade". O curso em questão pode se enquadrar como parte da medida protetiva ${ }^{3}$ e/ou como forma preventiva por meio do diagnóstico precoce da situação de violência. O segundo é voltado às mulheres inseridas no contexto de violência de gênero, em que participarão de eventos sobre empoderamento feminino e discussões sobre a violência doméstica. Já o terceiro, é voltado aos profissionais que atendem às mulheres em situação de violência doméstica, sendo um eixo de capacitação da rede de atendimento à mulher. O projeto conta com muitas parcerias, com Extensão "Just Imagine" da Universidade Federal da Paraíba (UFPB) e a Delegacia Especializada da Mulher de Polícia de Patos-PB.

Para BUTLER (2019, p. 189), ao frisar que a precariedade da vida tem relação com a possibilidade de ser vitimado, observa-se que algumas populações estão mais sujeitas à violência arbitrária que outras, em decorrência da vulnerabilidade. Assim, tendo como ponto de partida a adoção da condição de vulnerabilidade e a agressão como partes fundamentais da vida política, chegaríamos as respostas alternativas e não violentas às violações sofridas. Vale salientar que, o Direito Penal de Vulneráveis é tido como o uso do Direito Penal para proteção e afirmação de direitos de grupos que antes eram vítimas de sua seletividade ${ }^{4}$ (COSTA; BARRETO, 2015, p. 60)

A Defensora Pública do Estado de Pernambuco, Alice Santos ${ }^{5}$, em live realizada via instagram no dia 26 de maio de 2020, na página "Canal do Júri”, em que teve como tema "Desafios de uma feminista na defesa de casos de feminicídio", realçou alguns pontos importantes e que confirmam toda tese já apresentada neste artigo.

Também como na Paraíba, o Estado de Pernambuco enfrenta baixo números de Defensores Públicos o que requer uma equipe especial de júri para atuar no Plenário no Alto Sertão do Estado, muitas vezes desassisto, e nos casos em que, mesmo havendo Defensores Públicos na Comarca, eles se recusam a fazer o júri, na fase do Plenário.

3 É importante ressaltar que a Lei $n^{\circ}$ 13.984/2020 (publicada em 03/04/2020), acrescentou duas novas medidas protetivas de urgência à Lei Maria da Penha: comparecimento do agressor a programas de recuperação e reeducação (art. 22, VI); e acompanhamento psicossocial do agressor, por meio de atendimento individual e/ ou em grupo de apoio (art. 22, VII).

${ }^{4}$ A seletividade do sistema penal, segundo Alessandro Baratta (2002, p. 175-177), decorre do fato deste reproduzir as relações sociais (sejam elas racistas, sexistas e classistas) e servir para manter a estrutura vertical da sociedade, em que no poder está a classe hegemônica e no centro do controle as classes marginalizadas.

5 Defensora Pública do Estado de Pernambuco, em exercício na $3^{\text {a }}$ Vara do Tribunal do Júri da Capital e em acumulação nas Defesas em Plenário do Júri. 
Diante destas circunstâncias, a Defensora Pública de Pernambuco destacou que enfrenta dificuldade em construir a plenitude de defesa sem ter um contato prolongado com o réu, limitando-se, na maioria das vezes, a conhecê-lo e conversar com o mesmo no dia de seu julgamento. Essa situação traz para o réu uma sensação de insegurança, por ter o primeiro contato com o seu defensor de sua liberdade, apenas no dia do júri. O que pode gerar, assim, uma dissiparidade de armas entre a Promotoria de Justiça e a Defensoria Pública.

Essa insegurança é aumentada quando estamos diante de um caso de feminicídio, em que a defensora pública é mulher. Geralmente esses homens acusados, quando réus confessos, trazem consigo toda a questão estrutural do crime, com a consequente diminuição da mulher, sendo reflexo na (des)credibilidade da Defensora Pública. Alice Santos, em sua fala, ressaltou bem este ponto, ao fazer questão de ir "bem feminina e provocativa" ao júri, com um vestido justo, batom vermelho, salto alto, etc., momento em que o réu, ao vê-la se espantou, "é a senhora que vai fazer a minha defesa? A senhora não vai entender a minha história".

Essa tendência em descredibilizar a mulher no júri, transcende a figura do acusado, sendo também compartilhada pelos demais presentes, como Promotor e Juiz, segundo a Defensora. Argumentos sexistas, neste tipo de crime, são muito utilizados em Plenário, tanto para defender quanto para acusar. Por exemplo, em júri realizado pela defensora, o Promotor pôs em evidência o fato do casal (o réu e a vítima) ter se conhecido numa igreja e não em um "barzinho", isto é, criando uma imagem de mulher "moralmente respeitável". A defensora rebateu o argumento com o fato da mesma frequentar bares e não ser esse o motivo de classificar moralmente uma mulher, não a faz merecer ser vítima desse crime. O Promotor ainda tentou atingir a Defensora, ironizando o fato da mesma ser feminista e se encontrar atuando neste júri de feminicídio.

No campo da defesa, a Defensora comentou que muitos de seus colegas compactuam com a ideia de que defender o réu requer defender a sua personalidade, isto é, se o mesmo cometeu o crime para defender sua "honra" ou porque a mulher "merecia" (seja porque o "provocou" ao usar roupas decotadas ou batom vermelho) o defensor tinha que continuar com a mesma linha defensiva. Inclusive, vale ressaltar que essa era a aparência da vítima (roupa decotada e batom vermelho), a qual recebeu cerca de 5 facadas nos seios, no crime narrado pela Defensora Alice Santos. 
Contudo, a tese de defesa apresentada pela Defensora Pública do Estado de Pernambuco, Alice Santos, foi voltada aos aspectos sociais que rodeiam o crime: o machismo estrutural. O fato desses homens terem sido criados em meio a essas concepções patriarcais, principalmente aqueles que moram no alto sertão dos Estados. Ademais, a Defensora Alice Santos disse que o ideal seria jamais utilizar-se de argumentos sexistas para defender o assistido, e assim evitar perpetuação dessa cultura discriminatória, uma vez que também se faz necessário impor limites (éticos) no júri.

Ainda em sede da defesa, foi ressaltado a importância das políticas públicas do Estado a fim de conscientizar esses homens produtos de uma sociedade patriarcal. Ao levar em consideração os altos números de feminicídios ocorridos no Brasil, nota-se que a política punitivista do Estado não tem sido a melhor opção para lidar com os casos, além do Direito Penal ter como princípio a intervenção mínima do Estado. A Defensora Alice Santos completou "Eu quero sim a resposta do Estado, mas no início, e não encarcerando em massa [...] Mas o que o Estado quer não é acabar com o machismo, é encarcerar os homens pretos, pobres, porque são eles os vulneráveis [...] $\mathrm{Na}$ falta de política pública o cidadão paga pela omissão do Estado"; e ainda usou como exemplo os acidentes de trânsito devido ao uso de bebidas alcoólicas pelos motoristas, em que só diminuíram com a conscientização da população através das políticas públicas do Estado.

Na mesma linha, destaca-se os trechos do excelente artigo de Lavinie Pinho (2020, p.30), Defensora Pública do Estado da Bahia:

$\mathrm{E}$, se na capital o moinho de moer gente rompe com as estruturas mais sólidas de resistência, no interior, tudo isso se acentua gravemente. A pessoalização do jogo penal (ROSA, 2016) e as questões de gênero servem ao poder punitivo como forte elemento para fragilizar (ainda mais) a defesa criminal. $\mathrm{O}$ ritual reproduz o quadro mental paranoico (CORDERO, p. 51) do machismo: filmagens da defensora pelos agentes de segurança; "buchichos" de que o quórum das salas de audiência ficam cheios para ver se "ela" aguenta a pressão das audiências e do plenário; o olhar desconfiado do assistido à primeira vista e a fragilidade que é forjada pelos demais atores do sistema penal (CARVALHO, 2010) são práticas comuns ao ver uma mulher ocupando o lugar da defesa.

Assim, a Defensoria Pública enquanto expressão da democracia e instrumento de promoção de direitos humanos, deve-se estipular limites éticos, abstendo-se de usar práticas que sustentam violações estruturais de direitos humanos, a exemplo da tese de legítima defesa da honra ou o uso da expressão "crime de amor", como meio de defesa para os acusados (COSTA, Renata, 2015, p. 202). 


\section{O Plenário do Júri de Feminicídio na Comarca de João Pessoa - PB: a defesa elaborada por Defensores(as) Públicos(as)}

Neste momento, falar-se-á dos (poucos) julgamentos de feminicídios realizados por Defensores(as) Públicos(as) na Paraíba, no intervalo de 15 de agosto/2019 a 21 de março/2020, uma vez que houve suspensão de diversos julgamentos, a partir de 2020, devido à COVID-19. Neste ínterim, só foram realizados 02 (dois) julgamentos de Feminicídio em que a Defensoria Pública estadual teve atuação, dentre os 06 (seis) julgamentos marcados no geral na Pauta do Júri dentro do intervalo analisado por este Estudo de Caso. Passemos a análise, então, daqueles que foram acompanhados pela Defensoria Pública que é o nosso objeto de pesquisa:

Quadro 2 - Julgamentos de feminicídios na comarca de João Pessoa/PB

\begin{tabular}{|c|c|c|}
\hline & $\begin{array}{c}\text { FEMINICÍDIO DE GIZELY } \\
\text { MEDEIROS SOUZA DA SILVA } \\
\text { Processo } n^{\circ} \text { 0000939- } \\
33.2019 .815 .2002\end{array}$ & $\begin{array}{l}\text { FEMINICÍDIO DE SENDRIA } \\
\text { MIKAELLY DO NASCIMENTO } \\
\text { AQUINO } \\
\text { Processo } \text { n }^{\circ} \text { 0002977- } \\
86.2017 .815 .2002\end{array}$ \\
\hline Réu(s) & $\begin{array}{l}\text { Lucas Ferreira Cavalcante (réu } \\
\text { preso) }\end{array}$ & $\begin{array}{l}\text { Tales Edizio Maciel de Lima, vulgo } \\
\text { "Talis"; Eduardo Caetano da Silva, } \\
\text { vulgo "Duduzinho"; Paulo Renato do } \\
\text { Nascimento Souza, vulgo "Bruxo" } \\
\text { (réus presos). }\end{array}$ \\
\hline Data do Fato & 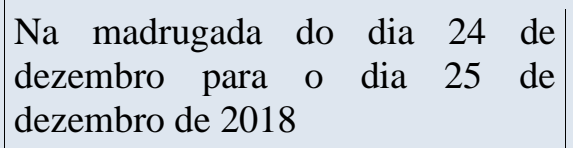 & 27 de fevereiro de 2017 \\
\hline Descrição do Fato & $\begin{array}{l}\text { Causa mortis: asfixia } \\
\text { As testemunhas que prestaram } \\
\text { depoimento em juízo, todas amigas } \\
\text { da vítima, relataram que, enquanto } \\
\text { o réu dormia, já no final da festa de } \\
\text { natal, a vítima Gisele pegou o } \\
\text { celular do mesmo e aparentou ter } \\
\text { visto mensagens da ex- } \\
\text { companheira do réu, o que a deixou } \\
\text { enfurecida, chegando a quebrar o } \\
\text { copo de sua bebida. } \\
\text { Após o encerramento da festa, com } \\
\text { a ida das testemunhas, a vítima foi } \\
\text { dormir com o réu. Na manhã } \\
\text { seguinte, os amigos retornaram à } \\
\text { casa da vítima pois haviam } \\
\text { esquecido alguns pertences e iriam } \\
\text { ajudá-la na limpeza da casa, } \\
\text { momento em que depararam com o } \\
\text { réu saindo do local. Ao adentrarem } \\
\text { ao quarto da vítima, perceberam }\end{array}$ & $\begin{array}{l}\text { Morte em decorrência de projétil de } \\
\text { arma de fogo. } \\
\text { O encontro entre a vítima e os réus foi } \\
\text { marcado em decorrência da mesma } \\
\text { ter prometido a Tales uma quantia em } \\
\text { dinheiro para ajudá-lo com um } \\
\text { advogado, que seria entregue a seus } \\
\text { amigos. A vítima se encontrava } \\
\text { dentro de um uber, quando os dois } \\
\text { réus passaram na moto e dispararam } \\
\text { contra o corpo da mesma. } \\
\text { O motorista do uber socorreu a } \\
\text { vítima, levando-a para a emergência. } \\
\text { Mesmo sendo prontamente atendida e } \\
\text { ter se mantido consciente por alguns } \\
\text { dias, a vítima não resistiu aos } \\
\text { ferimentos e faleceu. }\end{array}$ \\
\hline
\end{tabular}




\begin{tabular}{|c|c|c|}
\hline $\begin{array}{l}\text { Motivação do } \\
\text { Crime }\end{array}$ & $\begin{array}{l}\text { Versão das testemunhas de } \\
\text { acusação (amigas da vítima): } \\
\text { ciúmes da vítima em decorrência da } \\
\text { mesma ter pego o celular do réu e } \\
\text { ter, supostamente, visto mensagens } \\
\text { da ex-companheira do réu; } \\
\text { Versão do réu: possibilidade dos } \\
\text { amigos da vítima terem praticado o } \\
\text { crime, tendo como motivo as } \\
\text { desavenças entre a vítima e uma } \\
\text { amiga, devido a um ex em comum } \\
\text { ou por ciúmes do réu. }\end{array}$ & $\begin{array}{l}\text { Consoante os autos, a vítima disse } \\
\text { que deixaria de visitar o réu Tales } \\
\text { (que se encontrava preso no presídio } \\
\text { do Roger por roubo), cancelando sua } \\
\text { autorização de visita e que não mais } \\
\text { manteria o relacionamento com o réu. } \\
\text { Diante disso, o réu, por não aceitar o } \\
\text { término e distanciamento da vítima, } \\
\text { mandou dois amigos Duduzinho e } \\
\text { Bruxo matá-la. }\end{array}$ \\
\hline Data do Júri & 11 de novembro de 2019 & 10 de fevereiro de 2020 \\
\hline $\begin{array}{l}\text { Defensor(es) } \\
\text { Público(s) }\end{array}$ & Dr. José Celestino Tavares de Souza & $\begin{array}{l}\text { Dr. José Celestino Tavares de Souza; } \\
\text { Dra. Neide Luiza Vinagre Nobre }\end{array}$ \\
\hline Tese da Defesa & $\begin{array}{l}\text { Negativa de autoria, valendo-se da } \\
\text { ausência de provas no processo que } \\
\text { atestassem ser o réu o autor do } \\
\text { delito, prevalecendo o princípio do } \\
\text { in dubio pro réu, na segunda fase do } \\
\text { júri. }\end{array}$ & $\begin{array}{l}\text { Tales: negativa de autoria, devido à } \\
\text { insuficiência de provas; } \\
\text { Duduzinho: réu confesso; pedido de } \\
\text { redução da pena por menor } \\
\text { participação c no } \\
\text { desclassificação para homicídio } \\
\text { simples; } \\
\text { Bruxo: negativa de autoria, devido à } \\
\text { insuficiência de provas. }\end{array}$ \\
\hline Tese da Acusação & $\begin{array}{l}\text { Homicídio qualificado por motivo } \\
\text { torpe, meio que impossibilitou a } \\
\text { defesa da vítima e feminicídio }\end{array}$ & $\begin{array}{l}\text { Tales: mandante do crime. Homicídio } \\
\text { qualificado por motivo torpe, meio } \\
\text { que impossibilitou a defesa da vítima } \\
\text { e feminicídio; } \\
\text { Duduzinho: Homicídio qualificado } \\
\text { por motivo torpe, meio que } \\
\text { impossibilitou a defesa da vítima. } \\
\text { Bruxo: Homicídio qualificado por } \\
\text { motivo torpe, meio que } \\
\text { impossibilitou a defesa da vítima. }\end{array}$ \\
\hline Veredito do Júri & $\begin{array}{l}\text { Réu condenado por homicídio } \\
\text { qualificado por motivo torpe, meio } \\
\text { que impossibilitou a defesa da } \\
\text { vítima e feminicídio }\end{array}$ & $\begin{array}{l}\text { Tales: Réu condenado homicídio } \\
\text { qualificado por motivo torpe, meio } \\
\text { que impossibilitou a defesa da vítima } \\
\text { e feminicídio; } \\
\text { Duduzinho: Réu condenado por } \\
\text { homicídio qualificado por motivo } \\
\text { torpe, meio que impossibilitou a } \\
\text { defesa da vítima; } \\
\text { Bruxo: Réu condenado por homicídio } \\
\text { qualificado por motivo torpe, meio } \\
\text { que impossibilitou a defesa da vítima. }\end{array}$ \\
\hline
\end{tabular}


\begin{tabular}{l|l|l}
$\begin{array}{l}\text { Presença de SIM. } \\
\text { Emissoras de TV }\end{array}$ & SIM. \\
\hline Fonte: Audiencis do Plenărio do Tribunat do Júri da Comaca de
\end{tabular}

Fonte: Audiências do Plenário do Tribunal do Júri da Comarca de João Pessoa/PB, dias: 11 de novembro de 2019 e 10 de fevereiro de 2020.

A seguir, será feita uma análise do julgamento no Tribunal do Júri de Lucas Ferreira.

O representante do Ministério Público, a fim de construir o perfil do réu como criminoso habitual, destacou que o mesmo era suspeito de um roubo à mão armada. Contudo, não havia nenhum inquérito policial em andamento, nem nada que pudesse atestar o envolvimento do réu com o ocorrido. Fato bastante questionado pelo Defensor Público. Como acusar alguém de um fato sem haver provas e usar sua posição pública enquanto promotor de justiça para ludibriar os jurados? (Fez pergunta semelhante em Plenário).

Não só o Ministério Público estava preocupado em traçar o perfil do réu, mas também o Defensor Público, ao realçar que o réu possuía trabalho formal e não era uma pessoa violenta. Assim, a ex-companheira do réu, mãe de seu filho de 3 anos, compareceu como testemunha de defesa.

O depoimento da ex-companheira do réu, a qual foi ouvida como declarante, foi de suma importância, uma vez que montou um perfil de pessoa não violenta para o réu, destacando o relacionamento saudável vivenciado pelos dois, além de delinear sobre o relacionamento do réu com o filho do casal, com pagamento regular da pensão alimentícia. A declarante, por fim, ressaltou que o réu continuava a mandar mensagens para ela, sendo todas sobre o filho, até porque a mesma se encontrava (no dia do julgamento) casada com outro. O Defensor Público completou que o réu nunca foi preso ou processado, não tendo, então, antecedentes criminais, rebatendo o perfil ora criado pelo Promotor de Justiça.

Quanto à presença de duas emissoras de Tv locais no julgamento, é importante verificar se a imagem dos jurados é preservada e o quanto que este cenário pode influenciar no julgamento dos mesmos, uma vez que a repercussão social pode interferir no veredicto do júri.

Embora a lei seja pública, os jurados, enquanto pessoas leigas, tendem a possuir pouco conhecimento técnico a respeito da legislação e das regras de sua interpretação. Por isso, é muito criticada o Tribunal do Júri, palco de julgamento dos piores crimes tipificados em nosso ordenamento, por ser formado por juízes leigos e não um juiz togado. 
Em seu interrogatório, o réu relatou que no dia do fato, a vítima fez uso de drogas (cocaína) e que não possuía a senha de seu celular, o qual amanheceu descarregado.

Primeiramente, em relação a fala do Promotor de Justiça no debate, destaca-se frases como "Quem pode consumir droga é ele. A menina não. A menina era moça direita"; "Família, pode ficar tranquila que ele será condenado"; "Falta de 'hombridade' dele de assumir o que fez"; "Não temos nada contra ele, mas contra o crime, porque ninguém pode matar uma mulher"; além de ter utilizado o fato da família se encontrar no julgamento para reiterar que alguém precisava pagar pelo crime, por justiça a família "Vamos mostrar a família que os jurados da Capital são justos e sairá hoje com uma condenação", sempre enfatizando a grande quantidade de feminicídios ocorridos. A fala do Promotor se centrava na necessidade de culpar alguém pelo crime, pois só assim existiria justiça para família.

Com isso, tem-se, por exemplo, frases sexistas com o intuito de construir uma imagem de uma mulher "moralmente" aceita, ao negar a possibilidade da mesma usar drogas. O principal a ser destacado em seu discurso é a forma que as concepções jurídicas eram passadas para os jurados. Frases como "quem mata mulher pratica feminicídio" desvirtuam os jurados que não possuem o conhecimento técnico, forçando (erroneamente) a imputação da qualificadora do feminicídio (inciso VI, §2º art. 121, CP).

O Defensor Público, especificamente, foi bastante cuidadoso em demonstrar adequadamente a necessidade dos requisitos estarem presentes da qualificadora (que não se configurava no caso julgado). Ressaltou também a importância da previsão da qualificadora na lei, "Sobre hipótese nenhuma, pode haver a desigualdade e a descriminação contra a mulher”. Por isso pediu, subsidiariamente, que a qualificadora fosse afastada.

O Defensor ainda utilizou frases como: "Não se vê feminicídio nenhum no processo"; "Não há, nos autos, nada em relação a coabitação violenta ou algum aspecto ruim do relacionamento entre o réu e a vítima"; "Há quem entenda que, se a vítima for mulher, resta caracterizado o feminicídio, mas deve-se analisar as provas, uma vez que se julga o direito do fato e não do autor; Não há provas de violência, discriminação... ou que ele a desrespeitava tanto no ambiente privado quanto no público”.

A má instrução também se consolidava na ausência do toxicológico da vítima e do réu no processo, a inexistência de exame pericial para extrair (se houvesse) os resíduos nas unhas do réu, além da falta de perícia no celular, a fim de verificar as mensagens 
relatadas pelas testemunhas da acusação, "Não podemos ficar no achismo", o Defensor acrescentou.

O Defensor, além de apresentar a tese de negativa de autoria, preocupou-se em contestar a qualificadora do motivo torpe, "É preciso ter motivação no crime de homicídio, mas não há motivos nos autos"; "Ninguém viu e ninguém sabe o motivo". Como forma de rebater o Defensor Público, o Promotor de Justiça na réplica contraargumentou usando a progressão de regime, uma vez que homicídio qualificado gerava outra fração a ser aplicada para a progressão, uma mais rigorosa.

Ainda analisando a fala do Defensor Público, destaca-se alguns aspectos de conotação religiosa, como "Julgar tem um pouco de onipotência de Deus que é condenar e absolver um semelhante" e de conotação social da política criminal do Estado "Os Defensores são a boca de quem não tem voz, o grito de quem é excluído", destacando o caos nas prisões, como a violência e o fato de "Na cadeia só entra pobre e negro".

Outro aspecto importante é a presença e o comportamento da família da vítima em Plenário. Episódios como: a fala alta da mãe, no momento da defesa, indignada pelo réu está sendo defendido; sua posterior saída, chamando a atenção dos jurados, aliam-se ao discurso do Promotor de Justiça da necessidade dos jurados fazer justiça pela família ali presente, "A família e as pessoas querem a condenação; Eu fico solidário com a família porque é duro e o advogado vir falar que o réu está correto".

Mesmo sendo advertidos (os familiares da vítima presentes com suas conversas altas - propositadamente -) pelo juiz, o qual invocou o artigo 497 do Código de Processo Penal, as consequências não podem ser ignoradas como parte para formação da convicção dos jurados.

No que diz respeito ao segundo júri (julgamento dos réus: Tales, Duduzinho e Bruxo), destaca-se que os aspectos ligados ao feminicídio em si não foram muito discutidos em juízo pelo Promotor. Houve também o fato do réu Tales já ter tentado suicídio quando apreendido pela prática de ato infracional, devido à também tentativa de Sendria de findar com o relacionamento já vigente na época.

Mesmo não havendo provas suficientes que comprovassem ser Paulo Renato o "Bruxo", houve o encarceramento do pobre e do negro. Tales era integrante da facção paraibana "Okaida" desde os treze anos de idade, fato que foi bastante utilizado pelo Promotor de Justiça como motivo para condená-lo, além da justiça pela família, mostrando a mídia da família (mãe e tia da vítima) chorando. 
Com isso, o principal aspecto a ser apontado na análise do julgamento é a falta de estrutura da instituição da Defensoria Pública em construir a plenitude de defesa, uma vez que não faz o acompanhamento processual desde o início, ou se faz, não há a identidade física do Defensor, nem a possibilidade de atuar como defesa investigativa.

\section{CONCLUSÃO}

Diante da discussão impetrada neste artigo, pode-se finalizar pontuando que argumentos que reafirmam a ordem patriarcal da sociedade, devem ficar de fora da fala dos Defensores em Plenário, como por exemplo, a tese de legítima defesa da honra ou de crime passional nos casos de Feminicídio no Tribunal do Júri, sendo substituídos pelo argumento da cultura de discriminação, em que se produz uma série de omissões estatais, as quais fazem o autor da violência de gênero uma vítima “cultural”. Existem, portanto, elementos latentes da Cultura Patriarcal presentes nas práticas e atitudes dos sujeitos em seu cotidiano que determinam violências e valores subterrâneos de ordem machista e dominante, impedindo o pleno reconhecimento da igualdade de gênero e dos direitos das mulheres. Poder-se-ia, até mesmo, falar em "machismo estrutural" que contamina as relações humanas de gênero, impedindo o desenvolvimento de uma proteção social mais ampla às mulheres. Todavia, uma parcela desses sujeitos, formados dentro dessa estrutura, também se encontra vulnerável em razão da desigualdade social, merecendo uma análise de culpa de acordo com critérios que o estabeleçam como produto desse processo cultural hegemônico.

Ademais, como um fenômeno multifaces, a solução para o problema da violência doméstica, está além da intervenção penal que também funciona por meio de um sistema sexista e seletivo, segundo a visão estabelecida a partir da crítica insurgente de um Direito Penal dos Vulneráveis, sendo necessário, para além das mudanças institucionais e discursivas, a criação de políticas públicas possíveis de serem executadas no âmbito da Defensoria Pública.

Dessa forma, a Defensoria poderá realizar harmonicamente suas duas funções: promover os direitos humanos e prestar assistência judiciária gratuita sem atuar de forma antagônica aos seus princípios. A percepção além da vítima é de suma importância para modificar o pensamento machista que é reproduzido pela sociedade e "executado" pelos réus. Por isso a necessidade de políticas públicas para modificar esse cenário, com projetos específicos voltados para o atendimento e tratamento dos agressores. Apenas ampliando essa visão e tornando as redes de atendimento mais abertas e complexas vamos 
poder romper com esse ciclo de violência de gênero, responsável pela morte de centenas de mulheres no Brasil.

\section{REFERÊNCIAS}

BOURDIEU, Pierre. A dominação masculina. KÜHNER, Maria Helena (tradução). 11. ed. Rio de Janeiro: Bertrand Brasil, 2012.

BRASIL. [Código Penal]. Decreto-Lei no 2.848, de 7 de dezembro de 1940. Brasília, DF: Presidência da República. Disponível em:

http://www.planalto.gov.br/ccivil_03/decretolei/del2848compilado.htm. Acesso em: 16 out. 2020.

BRASIL. [Lei Maria da Penha]. Lei no 11.340, de 7 de agosto de 2006. Brasília, DF: Presidência da República. Disponível em:

http://www.planalto.gov.br/ccivil_03/_ato2004- 2006/2006/lei/111340.htm. Acesso em: 16 out. 2020.

BRASIL. Lei Complementar no 80, de 12 de janeiro de 1994. Brasília, DF:

Presidência da República. Disponível em:

http://www.planalto.gov.br/ccivil_03/leis/lcp/lcp80.htm. Acesso: 02 de ago. de 2020.

BUTLER, Judith. Vida precária: os poderes do luto e da violência. Trad. Andreas

Lieber. Belo Horizonte: Autêntica, 2019.

CAMPOS, Carmen Hein de. Criminologia Feminista: teoria feminista e crítica às criminologias. Rio de Janeiro: Editora Lumen Juris, 2017.

CARVALHO, Salo de. Anti-Manual de Criminologia. 4a ed. Rio de Janeiro: Editora Lumen Juris, 2011.

CNJ. [Conselho Nacional de Justiça]. Em 5 anos, 86 casos foram tipificados como feminicídio. 2019. Disponível em: <https://www.cnj.jus.br/em-5-anos-86-casos-deassassinatos-de-mulheres-foramtipificados-como-feminicidio/>. Acesso em $5 \mathrm{de}$ abr. de 2020 .

COSTA, Daniela Carvalho Almeida; BARRETO, Daniela Ramos Lima. Direito Penal dos Vulneráveis: uma análise crítica da busca do reconhecimento por meio do direito penal. Revista de Criminologia e Políticas Criminais. Minas Gerais, 2015. v.1, n.2. P. 57-83. Disponível em: https://indexlaw.org/index.php/revistacpc/article/view/34. Acesso em: 15 out. 2020.

COSTA, Renata Tavares. Os diretos humanos como limite ético na defesa dos acusados de feminicídio no Tribunal do Júri. Livro de Teses do XII Congresso Nacional dos Defensores Públicos, 2015. P. 201-208. Disponível em: https://assets-dossiesipgv2.nyc3.digitaloceanspaces.com/sites/4/2016/03/OS-DIREITOS-HUMANOSCOMOLIMITE-\%C3\%89TICO-NA-DEFESA-DOS-ACUSADOS.pdf. Acesso em: 31 out. 2020 .

FRASER, Nancy. Da redistribuição ao reconhecimento? Dilemas da justiça numa era "pós-socialista". Cadernos de Campo (São Paulo 1991), v. 15, n. 14-15, 30 mar. 2006.

INSTITUTO DE PESQUISA ECONÔMICA APLICADA; FÓRUM BRASILEIRO DE SEGURANÇA PÚBLICA (Orgs.). Atlas da violência 2018. Brasília; Rio de 
Janeiro; São Paulo: IPEA; FBSP, 2018 Disponível em:

http://www.ipea.gov.br/portal/images/stories/PDFs/relatorio_institucional/180604_atlas _da_violencia_2018.pdf. Acesso em: 27 de abr. de 2019.

OLIVEIRA, Ana Sofia Schimidt de. Vitimologia e Mulher In: REALE Jr., Miguel; PASCHOAL, Janaína (coords.). Mulher e Direito Penal. Rio de Janeiro: Editora Forense, 2007.

PERROT, Michelle. Os Excluídos da História: operários, mulheres e prisioneiros. Trad. Denise Bottmann. 4a ed. Rio de Janeiro: Editora Paz e Terra, 2006.

RASTIER, François. Ação e Sentido por uma Semiótica das Culturas. BATISTA, Maria Fátima Barbosa de Mesquita (tradução). João Pessoa: Editora Universitária da UFPB, 2010.

SANTOS, Michelle Moraes. Violência doméstica: enfrentando o problema em rede In: Gênero, feminismos e sistemas de Justiça: discussões interseccionais de gênero, raça e classe. Luciana Boiteux, Patricia Carlos Magno, Laize Benevides (Orgs.). - Rio de Janeiro: Freitas Bastos, 2018. P. 497 - 513.

SARLET, Ingo Wolfang. A eficácia dos Direitos Fundamentais. $3^{a}$ ed. Porto Alegre: Editora

STF. [Supremo Tribunal Federal]. ADPF 779 MC-Ref/DF, Relator: Min. Dias Toffoli, Tribunal Pleno, julgado 13 mar. 2021. Disponível em: https://portal.stf.jus.br/noticias/verNoticiaDetalhe. asp?idConteudo=461297\&ori=1. Acesso em: 11 mai. 2021.

WAISELFISZ, Julio Jacobo. Mapa da Violência 2015: Homicídio de Mulheres no Brasil. Brasília - DF: Secretaria Especial de Políticas para as Mulheres/FLACSO, 2015. Disponível em:

https://www.mapadaviolencia.org.br/pdf2015/MapaViolencia_2015_mulheres.pdf Acesso em: 27 de abr. de 2019. 